Бистрова О. О. доктор філологічних наук, професор Дрогобиџький державний педагогічний університет ім. I. Франка

\title{
АНТРОПОЛОГІЗМ У ХУДОЖНІЙ ЛІТЕРАТУРІ
}

В статті розглядається позиція українських літературознавців щуодо антропологізму в літературі. Аналізуються антропологічні аспекти твору Ф. Достоєвського «Підліток». Розглядаються домінантні образи, особливості психологізму, як одного з складників антропологізму.

Ключові слова: антропологізм, духовність, контрадикторність, домінантний образ.

В статье рассматривается позищия украинских литературоведов относительно антропологизма в литературе. Анализируются атропологические аспекты произведения Ф. Достоевского "Подросток". Рассматриваются доминантные образы, особенности психологизма, как одной из составляющих антропологизма.

Ключевые слова: антропологизм, духовность, контрадикторность, доминантный образ. 
The article considers the position of Ukrainian literary criticismabout anthropologism in literature. Anthropological aspects of the work «Podrostok» by Fyodor Dostoevsky were analyzed. The author considers the dominant images, and features of psychology, as one of the pillars of anthropologism.

Keywords: anthropologism, spirituality, contradiction, dominant image.

Останнім часом все більше увагу дослідників привертає антропологічний аспект дослідження художніх творів. Питання про антропологію тексту ставлять закордонні та вітчизняні дослідники. М. Гольберг в статті «Антропологія художнього тексту» зазначає: «Антропологічний підхід дозволяє вивчити роль людини у культуротворчих процесах, у творенні історії, у всіх галузях суспільної діяльності. Йдеться про те, що надає смислу історії, насичує іiї високою Духовністю. Йдеться врешті-решт про невичерпну силу людського Духа, про творчу енергію людини». Якщо М. Гольберг підкреслював саме важливість людського духу, то такі дослідники, як Гомілко та Ф. Штейнбук обрали об’єктами дослідження тілесний аспект. Гомілко звернув увагу в статті «Метафізика тілесності» на такі складові людського життя, як: народження, дитинство, вік, стать, хвороба, старість і смерть. Фелікс Штейнбук в статті «Тілесний міметизм (феномен монструозності)» простежує функціонування таких проявів тілесного міметизму, як «виродок», «каліка», «потвора» в творах Д. Ліпскєрова. Спираючись на думки Гегеля, Штейнбук припускає, що зовнішня об’єктивна, матеріальна оболонка співвідноситься 3 самосвідомістю особистості. [Штейнбук, 2007: 24-27]

Ще один дослідник, Подорога Валерій в монографії «Мімеcic. Матеріали по аналітичній антропології літератури», виданій в 2006 році, другу частину присвячує дослідженню творчості Достоєвського. Основна увага приділена темі двійництва.

Значну увагу творчості Достоєвського приділив і Дмитро Чижевський. Саме він називав Ф. Достоєвського антропологом. В його творчості дослідник знаходив риси глибокого людинолюбства. У своїх роботах про Достоєвського Чижевський часто згадує роман 
«Підліток», його героя Андрія Петровича Версілова, насамперед у зв'язку з проблемою двійництва.[Чижевський 2005: 360-383]

Нас цікавить, як прояви духовного життя і поведінки особистостей цього роману втілювалися в художній формі твору, суголосність цієї форми теоретичним засадам Чижевського і його власній авторський манері.

«...художній стиль Достоєвського побудовано на взаємопроникненні «натуралістичних» та ірреалістичних елементів. Проза й банальність життя примхливо переплітаються з фантастикою, натуралістичний малюнок - із пафосом абстрактної ідеї, тверезе прагнення до реальності - з екстатичним осягненням позамежного. I сила Достоєвського в тому, щзо ці полярнопротилежні, «суперечливі» елементи в ньому не просто змішані, а сплетені й зрощені в органічну єдність» [Чижевський 2005: 362]. Д.С. Лихачов називає стиль Ф. Достоєвського ірраціональним, а композицію імпресіоністичною [Лихачев 1971: 194].

Роман «Підліток» розгортає перед дослідником широке поле переконливих прикладів і доказів цих (і не лише цих) теоретичних постулатів Д.Чижевського та його власної мистецької практики. Досліджуючи романи Ф. Достоєвського, Д. Чижевський звертає увагу на досить розлогий комплекс проявів пульсуючих прикмет поетики, які формують цілісність стилю як «ситуативно пов'язану мову» [Энквист 1988: 330].

Роман «Підліток» за своїм пафосом - це сповідальний монолог «зацікавленої особи» - позашлюбного сина головного героя (Версілова) Аркадія Долгорукого. В цьому стилістично суцільному плині часто гарячкових спостережень і висновків можна спостерігати певні домінуючі «текстові атоми» (Н.Е.Енквіст) або «молекули стилю» (О. Чичерін). До них насамперед слід віднести наскрізні домінуючі образи, антитетику, паремії, прояви ритму прози, прояви таїни, численні гетерогенні асоціації, наприклад, шіллерівські: «Друже мій, це щзось шіллерівське!» [Достоевский 1975: 26]. 
Цьому питанню Д. Чижевський присвятив окрему статтю - «Шіллер і «Брати Карамазови».

Однією з концептуальних домінант як у творчості Чижевського, так і в структурі роману «Підліток» $є$ наскрізний образ - ідея. У «субстанційному характері людського буття (Д.Чижевський) ідея як текстовий атом набирає різних значень від філософсько-етичного до приземлено-натуралістичного, тому що « в людському бутті цілковито особливим чином переплітаються й поєднуються, зрощуються в конкретність... різноманітні форми, сфери і типи буття». [Чижевський 2005: 344]

Концепція синтетичного образу ідея розкриває себе паралельно у «Підлітку»: у світоглядних висловлюваннях Версілова й у гарячновій метушні та нервуванні Аркадія. Якщо у Версілова ㄹея має чітке філософське осмислення як «ідеал всепримирення ідей», який «стане згодом синтезом усіх шляхів, що їх Європа так довго й уперто випрацьовувала в окремих національностях» [Чижевський 2005: 346-347], то в Аркадія дея подрібнюється, за словами Д.Чижевського на натуралістичні та ірреалістичні елементи. Версілов мислить усталеними, типологізованими формулами, а в устах Аркадія вона функціонує полісемантично. Бажання розбагатіти, стати Ротшильдом, а значить самостійним, незалежним від обставин і людей Аркадій називає ідеєю. Отже у цьому сенсі ідея - це мета, підсилена жагучим меркантильним бажанням. Утаємничення, таїна, загадковість - це й мотив поведінки й риса особистості.

Чижевський не визнавав буття без загадок, буття в усіх його проявах: в людині та її вчинках, у перипетіях розвитку держав, у навколішньому середовищі. Для нього неприйнятною була позитивістська доба з людиною без загадок. Роман «Підліток» дає розгорнуте поле утаємничених ситуацій, ідей, вчинків, чуток, інтриг, які повинні тримати у постійній напрузі реципієнта. Постійні натяки, незавершені думки, обіцянки розказати щось пізніше, підтекст, неоднозначність оцінок, амбівалентність характерів - все це стає основою, підмурівком виникнення парадоксальних ідей. Чутки, 
навіть і безпідставні, це також ідей: «Про цю ідею я також чув. Мабуть, дурниці. [Достоевский 1975: 31]

Роман «Підліток» розгортає перед нами широкий простір дуалістичних зіткнень антропологічного (психологічного), філософського, морального, культурологічного, бутійно-екзистенційного характеру. Контрадикторний характер притаманний сюжетним зигзагам, портретним описам, мовним партіям героїв. «I сила Достоєвського в тому, що ці полярно-протилежні, «суперечливі» елементи в ньому не просто змішані, а сплетені й зрощені в органічну єдність. Немає сумніву, що цей стиль пов'язаний і з літературними традиціями (Гофман, Гоголь, Діккенс, Бальзак) і з глибинами особистих переживань Ф.Достоєвського. Вражають психологічні характеристики героїв, їхня розлога дуалістичність і несумісність у визначенні цілісної особистості. Очима сина батько повстає людиною не лише неоднозначною, але кричущо неоднозначною, 3 полярно протилежними рисами, які поступово ведуть Версілова до розщеплення свідомості, двійництва і божевілля: «Він сам, ця похмура й закрита людина, з тою милою простодушністю... говорив мені...» Розмитість меж між полярними людськими почуттями властива майже всім героям роману, насамперед Версіловим, батькові й синові. Свої непередбачувані вчинки Аркадій пояснює максимою, яка пізніше уславить Дмитра Карамазова - про широкість людини: «Хай живе широкість! Слід широко сприймати характери, чи не так?» Цю антитетичну широкість Д.Чижевський характеризував як основну тему антропології Ф.Достоєвського. Це твердження Ф.Достоєвського, що людина перебуває на межі двох сфер буття: «Зовнішнє, не залишається суто зовнішнім, а набирає форми буття «внутрішнього», проникає до внутрішнього, психічного життя людини. Душевне життя людини стає ареною боротьби обох світів, на межі яких стоїть людина».[Чижевський 2005: 345]

Саме балансування людини на межі двох сфер буття й обумовлює дуалізм людського життя і психологічні коливання особистості в різних ситуаціях. Чижевський вважає, що Достоєвський 
спостерігав подібні коливання й у самому собі. I про Чижевського дехто 3 його оточення міг би сказати словами Ф.Достоєвського: «Дійсно, повагу до себе він мав від усіх, проте, кажуть, що був для всіх нестерпним».

Через подібну амбівалентність і «полярну суперечливість» почуттів, думок і вчинків Ф.Достоєвський формує характери своїх провідних героїв, убачаючи в цьому не ущербність духу, а достоїнство і цінність людини як такої: «Тебе через відразу вони люблять!», «...і сам не знаю щохвилинно, що зло, що добро», «Мені це подобалося, і в той же час пригнічувало...», «тільки з роками печаль ніби з родістю змішуєтсья».

Амбівалентність стосується не лише людини, а й речей: «Кожна річ... може бути й велична і в той же час смішна».

Підлітку Аркадію (хоч йому й 19 років) Ф.Достоєвський дає право бути категоричним у своїх міркуваннях, висновках і спостереженнях, які часто набирають форм паремій, типологічних суджень. Аркадій до деякої міри своєрідний alter ego автора, його «повноважний представник». Принагідно нагадаємо, що і постать Д.Чижевського та Ф.Достоєвського сприймається сучасниками далеко неоднозначно, а у єдності вражаючих крайнощів. На цьому тлі виникла у Чижевського теорія ієрархічності людських душ.

Все це вказує на глибокий антропологізм творів Достоєвського. Чижевський відзначав цей аспект не тільки в творі «Підліток», але у всій творчості Федора Достоєвського.

\section{БІБЛІОГРАФІЯ}

Достоевский - Достоевский Ф.М. Полное собрание сочинений в тридцати томах. Т. 3 - Л.: Наука, 1975. - 530 с.

Энквист - Энквист Н. Э. Стили как стратегия в моделировании текста // Известия АН СССР, серия литературы и языка. - М., 1988, №4. - С. 329-340.

Лихачев - Лихачев Д.С. «Предисловный рассказ» Достоевского // Поэтика и стилистика русской литературы. Сб. ст. памяти академика В.В. Виноградова. Л.: Наука, 1971. - С. 189-195.

Чижевський - Чижевський Д. До проблеми двійника у Достоєвського // Д. Чижевський. Філософські твори у чотирьох томах. - Т.3 - К.: Смолоскип, 2005. C. $360-384$. 
Чижевський - Чижевський Д. Достоєвський - психолог // Д. Чижевський. Філософські твори у чотирьох томах. - Т.3. - К.: Смолоскип, 2005. - С. 343-360.

Штейнбук - Штейнбук Ф. Тілесний міметизм (феномен монструозності) у сучасній літературі // Слово і Час. - 2007. - №12. - С. 24-27.

Стаття надійшла 12 вересня 2013 р. 